ELEVATIONS OF BENCH MARKS, OBSERVATION WELLS, AND

PRODUCTION WELLS AT MATHER AIR FORCE BASE,

SACRAMENTO COUNTY, CALIFORNIA, 1988

By M.E. Ikehara, W.F. McCaffrey, and J.S. Williams

U.S. GEOLOGICAL SURVEY

Open-File Report 88-716

Prepared in cooperation with the

U.S. DEPARTMENT OF ENERGY

AND U.S. AIR FORCE, AIR TRAINING COMMAND

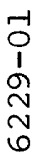




\section{DEPARTMENT OF THE INTERIOR}

DONALD PAUL HODEL, Secretary

U.S. GEOLOGICAL SURVEY

Dallas L. Peck, Director

For additional information

write to:
Copies of this report may be purchased from:

U.S. Geological Survey Books and Open-File Reports Federal Center, Bldg. 810 Box 25425

Denver, CO 80225
District Chief

U.S. Geological Survey

Federal Building, Rm W-2234

2800 Cottage way

Sacramento, CA 95825 


\section{CONTENTS}

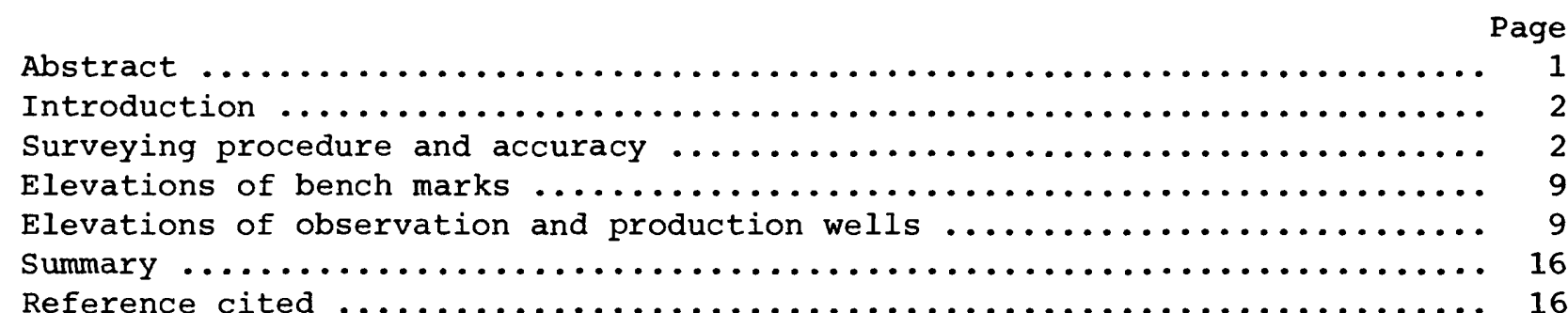

\section{ILLUSTRATIONS}

Figure 1. Map showing primary network of survey lines, bench marks

Page with historic data, and new bench marks for which elevations were obtained in June $1988 \ldots \ldots \ldots \ldots \ldots \ldots \ldots \ldots . \ldots 4$

2. Map showing observation and production wells for which elevations were obtained in June $1988 \ldots \ldots \ldots \ldots \ldots \ldots \ldots \ldots \ldots$

\section{TABLES}

Table 1. Summary of level closures for the five survey lines comprising the primary network .................... 8

2. Elevations determined from this survey and previous leveling surveys for selected bench marks ................ 10

3. Elevations and descriptions of new bench marks .............. 11

4. Elevations and descriptions of runway reference marks $\ldots \ldots \ldots \ldots 12$

5. Elevations of measuring point for observation wells $\ldots \ldots \ldots \ldots \ldots 13$

6. Elevations of measuring point and/or reference point of production wells, and adjacent land surface ............. 14 


\section{CONVERSION FACTORS}

For use of readers who prefer to use International system (SI) units, rather than the inch-pound terms used in this report, the following conversion factors may be used:

\section{Multiply}

foot $(f t)$

mile (m)

inches (in.)
$\underline{B y}$

0.3048

1.609

25.40
To obtain

meter (m)

kilometer $(\mathrm{km})$

millimeter (mm) 


\title{
ELEVATIONS OF BENCH MARKS, OBSERVATION WELLS, AND \\ PRODUCTION WELLS AT MATHER AIR FORCE BASE, \\ SACRAMENTO COUNTY, CALIFORNIA, 1988
}

By M.E. Ikehara, W.F. McCaffrey, and J.S. Williams

\begin{abstract}
Precise and accurate elevations of water-level-observation wells on Mather Air Force Base near Sacramento, California, were needed to determine the direction of ground-water flow at and near the base. A total of 19 miles of primary survey lines were run on or near Mather Air Force Base. The datum of these surveys is based on National Geodetic Survey bench mark y952 about 1.5 miles south of the base at the intersection of Jackson Highway (State Route 16) and Excelsior Road. The accuracy of these levels, based on National Oceanic and Atmospheric Administration standards, ranged between first and third order. Elevations of 41 bench marks, 76 observation wells, and 15 production wells on Mather Air Force Base were determined by differential leveling during June 1988. Levels were run to a designated measuring point on observation wells, to the pressure valve of production wells, to the land surface adjacent these wells, and to selected bench marks, some of which are on runways or taxiways.
\end{abstract}




\section{INTRODUCTION}

This report documents the elevations of 41 bench marks, 76 observation wells, 14 active production wells, and 1 former production well (figs. 1 and 2). Fourteen of the 41 bench marks were recently installed on Mather Air Force Base near Sacramento, California. This study was done by the U.S. Geological Survey, in cooperation with the U.S. Department of Energy and U.S. Air Force, Air Training Command, as part of the Installation Restoration Program. The Installation Restoration Program has the objectives of identifying, evaluating, and mitigating potential problems caused by past handling and disposal of toxic/hazardous materials at Air Force facilities. The ultimate goal of the program is to prevent movement of any toxic or hazardous materials into areas where health and property could be endangered.

One aspect of the Installation Restoration Program is to determine flow directions of shallow ground water by measuring depth to the water table at observation wells. Because of the small topographic relief near the base, precise and accurate elevations of the measuring point on the wells are required.

The purpose of this study was to determine elevations of various bench marks, observation wells, and production wells on the base to a common datum; in this case, the National Geodetic Vertical Datum of 1929. In addition, a number of bench marks on runways and taxiways were included in the level network.

Surveying on the base was accomplished through the efforts of several individuals. Access to sensitive areas on the base and to the observation wells was facilitated by Lt. Col. Richard Blank of the Environmental Management Section. Mr. Richard Udell, Base Surveyor, served as liason between base security, SAC security, and the surveying crews, provided information on existing base bench marks, and helped install new bench marks on the base.

\section{SURVEYING PROCEDURE AND ACCURACY}

The differential leveling surveys were completed during June 1988 with most of the work completed during the morning hours. Field weather conditions, such as temperature and wind, generally were moderate during the survey period and tended to reduce the magnitude of error caused by refraction, and expansion and contraction of survey rods.

Equipment used in the surveys included the Zeiss $\mathrm{Ni2} 2^{l}$ automatic compensating level, maintained in adjustment, and Philadelphia rods of the Lietz Precise Series. Foresight and backsight distances were balanced to reduce collimation error.

${ }^{1}$ Use of brand names in this report are for identification purposes only and does not constitute endorsement by the U.S. Geological Survey. 
Bench marks used were previously established by the National Geodetic Survey, U.S. Engineering Department, and the U.S. Bureau of Reclamation. All elevations for the U.S. Geological Survey 1988 leveling surveys are based on the elevation of National Geodetic Survey bench mark Y952, which was established in 1962 and is about 1.6 miles south of bench mark HG-1 (fig. 1). Bench mark Y952 is in the top of the concrete head wall of double box culvert A-5.92, southwest of the intersection of Jackson Road (State Route 16) and Excelsior Road. Bench mark 2955 is set vertically in the center of the north face of the concrete porch of the building at 9978 Folsom Boulevard. This bench mark, also established in 1962 by National Geodetic Survey, was leveled to but was found disturbed. Thus, it was not used in setting the datum for the Geological Survey 1988 leveling surveys because the concrete porch had cracked and settled.

A total of 19 miles were surveyed to form the primary network (fig. 1). Survey line $A$, to the south, and line B, to the north, originated from bench marks off the base. Line $C$, comprised of seven segments, totaled 8.94 miles. Segment D2, 1.26 miles, was part of line D that was 3.55 miles in length. Segment E6, $0.80 \mathrm{mile}$, was part of line $E$ that was 2.92 miles in length. Because segment D2 was adjusted on the basis of the closure of line D, 1.26 miles was subtracted from 8.94 miles, line C's total length. The other segments of line $C$ were then adjusted for a difference of 0.087 foot in closure for the remaining 7.68 miles.

The National Oceanic and Atmospheric Administration, Federal Geodetic Control Committee (1980) (formerly National Geodetic Survey) has defined standards of accuracy for vertical-control surveys. These standards are based, in part, on the distance surveyed. The maximum closures for survey lines are computed as follows: Second order, class I-- $6 \mathrm{~mm} \sqrt{\mathrm{K} ;}$ second order, class II-$8 \mathrm{~mm} \sqrt{\mathrm{K}}$; and third order--12 $\mathrm{mm} \sqrt{\mathrm{K}}$, where $\mathrm{K}$ equals one-half the total survey line distance, in kilometers.

The accuracy of the U.S. Geological Survey 1988 leveling surveys is based on closure differences for the survey lines. Lines $\mathrm{C}$ and $\mathrm{E}$ are third order, and lines A, B, and D are better than third order standard of accuracy . closure differences ranged between 0.001 and 0.087 foot and had an absolute average of 0.032 foot. Adjustments for the various survey line and segment closures were based on line length. A summary of the level closures for the five survey lines comprising the primary network (fig. 1) is given in table 1. Once the primary network was established, levels to the observation wells, the production wells, and other bench marks were run as closed survey lines from the primary network. Locations of observation and production wells are shown in figure 2 . 


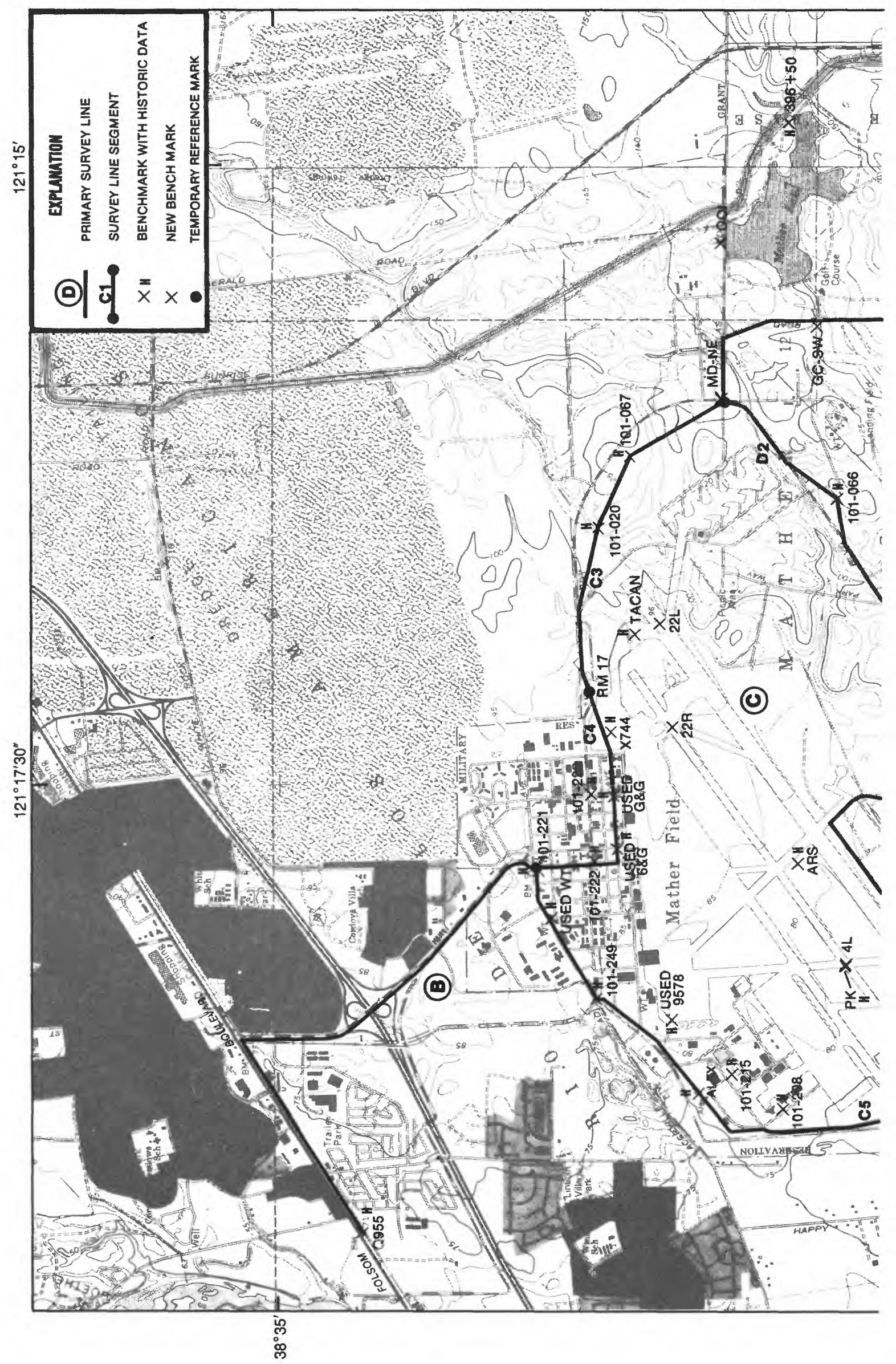




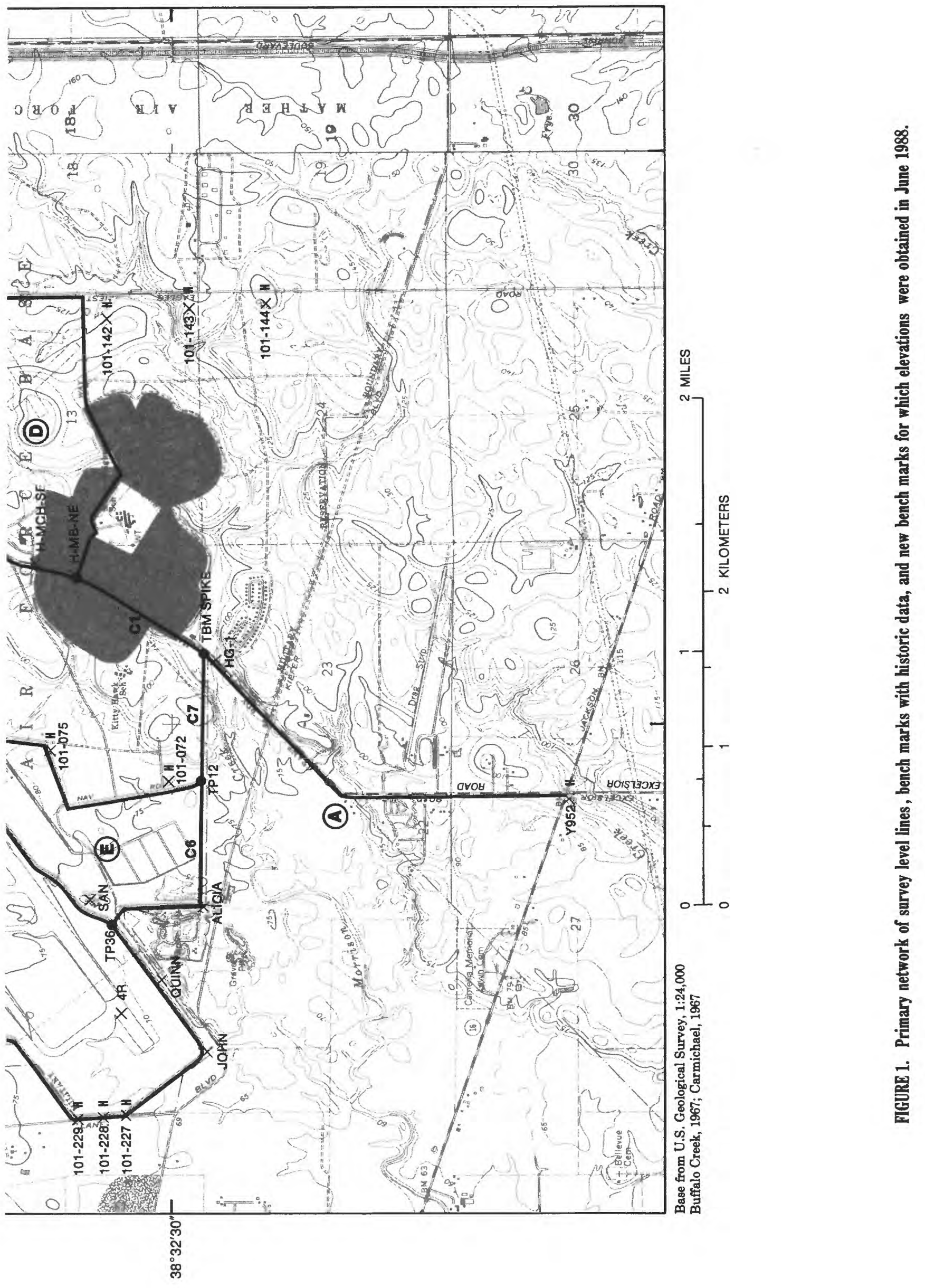




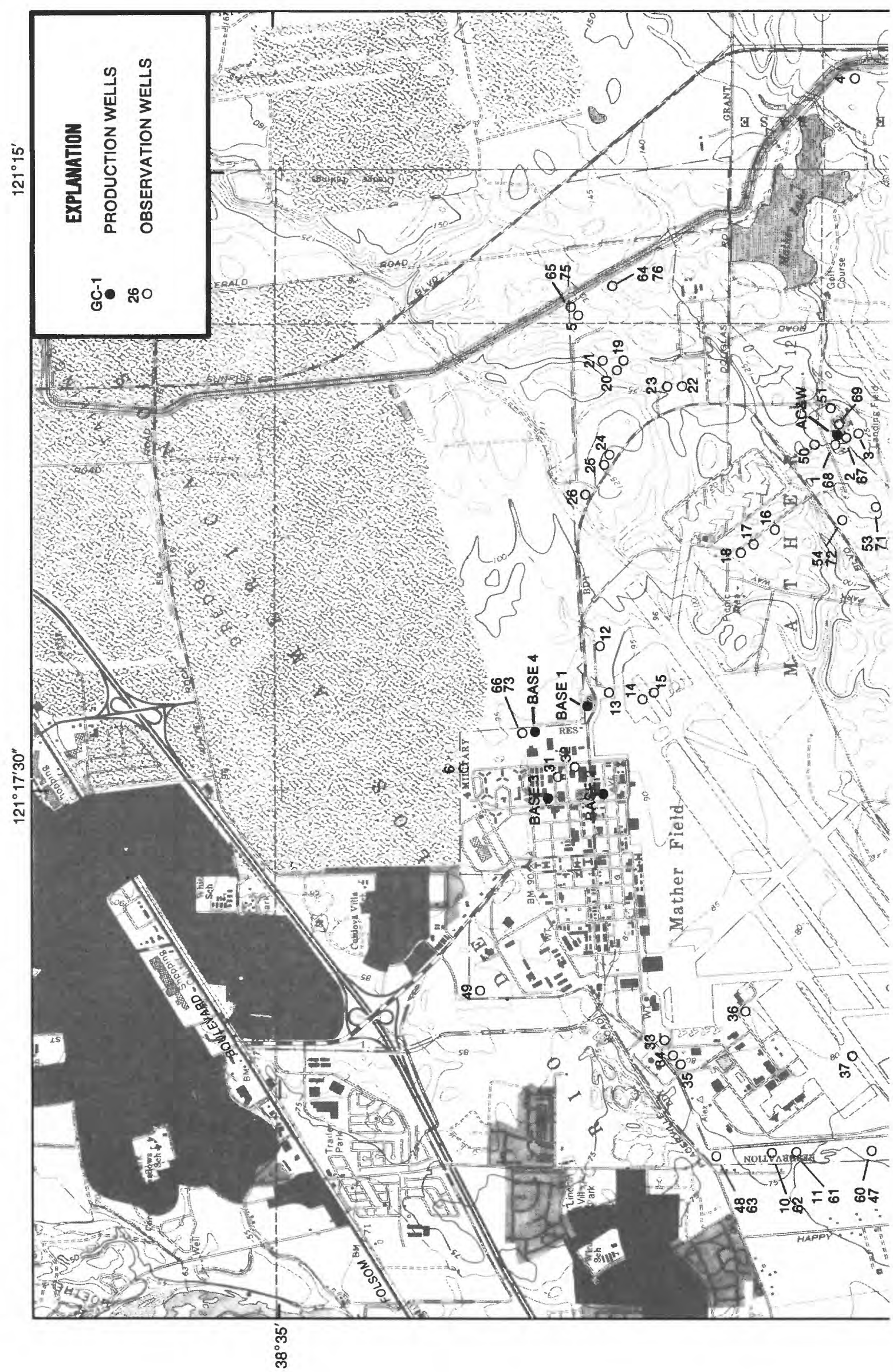




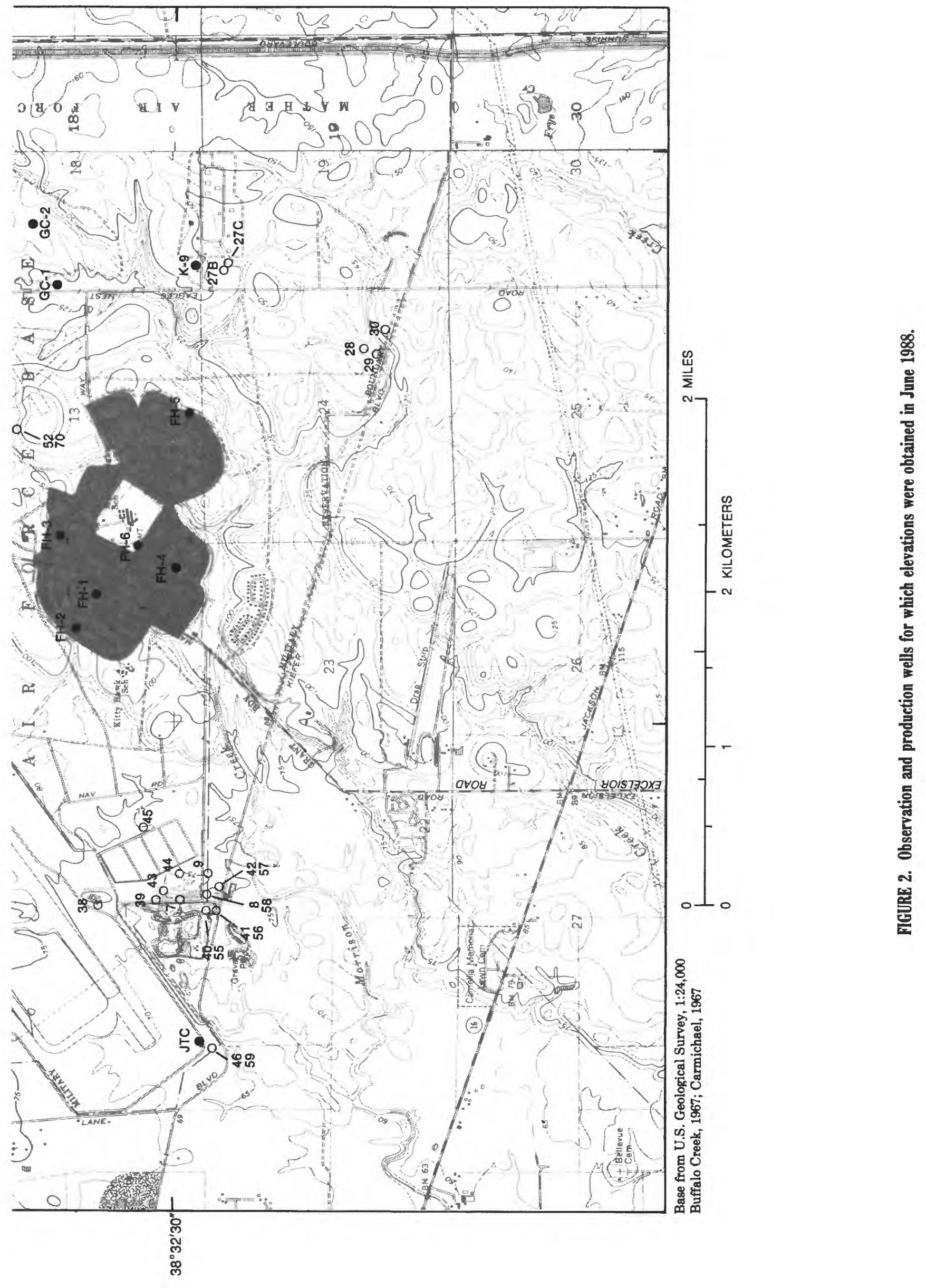


TABLE 1.--Summary of level closures for the five survey lines comprising the primary network

\begin{tabular}{|c|c|c|c|c|c|}
\hline $\begin{array}{l}\text { Survey } \\
\text { line } \\
\text { (fig. 1 }\end{array}$ & $\begin{array}{l}\text { Survey } \\
\text { Iine } \\
\text { segment }\end{array}$ & $\begin{array}{l}\text { Survey } \\
\text { line name }\end{array}$ & $\begin{array}{l}\text { Survey } \\
\text { line } \\
\text { segment } \\
\text { length } \\
\text { (miles) }\end{array}$ & $\begin{array}{l}\text { Total survey } \\
\text { line length } \\
\text { (miles) }\end{array}$ & $\begin{array}{l}\text { Closure } \\
\text { (foot) }\end{array}$ \\
\hline A & -- & $\begin{array}{l}\text { Y952 to TBM Spike } \\
\text { and return }\end{array}$ & - & 3.35 & +0.004 \\
\hline B & -- & $\begin{array}{l}Q 955 \text { to } 101-221 \\
\text { and return }\end{array}$ & -- & 2.2 & +.004 \\
\hline \multirow[t]{8}{*}{ C } & $\mathrm{C} 1$ & TBM Spike to H-MB-NE & 0.61 & -- & - \\
\hline & D2 & $\mathrm{H}-\mathrm{MB}-\mathrm{NE}$ to $\mathrm{MD}-\mathrm{NE}$ & ${ }_{1}^{1} .26$ & -- & -- \\
\hline & C3 & MD-NE to RM17 & 1.34 & -- & -- \\
\hline & $\mathrm{C} 4$ & RM17 to $101-221$ & 0.95 & -- & -- \\
\hline & C5 & $101-221$ to TP36 & 3.48 & -- & -- \\
\hline & E6 & TP36 to TP12 & ${ }^{1} 0.80$ & -- & -- \\
\hline & C7 & TP12 to TBM Spike & 0.50 & -- & -- \\
\hline & Total for & line $\mathrm{C}$ segments only & -- & 6.88 & .087 \\
\hline D & -- & $\begin{array}{l}\mathrm{MB}-\mathrm{NE} \text { to } \mathrm{MD}-\mathrm{NE} \\
\text { to } \mathrm{MB}-\mathrm{NE}\end{array}$ & -- & 3.55 & +.001 \\
\hline $\mathrm{E}$ & -- & $\begin{array}{l}\text { TP12 to TP } 36 \\
\text { to } \operatorname{TP} 12\end{array}$ & -- & 2.92 & -.063 \\
\hline
\end{tabular}

${ }^{1}$ These segment distances are included in totals for lines $D$ and $E$, as applicable. 


\section{ELEVATIONS OF BENCH MARKS}

Elevations determined from this survey and previous leveling surveys for selected bench marks are shown in table 2. Elevations for previous leveling surveys were furnished by Mather Air Force Base, private contractors, and other Federal agencies. Bench mark X744 was found slightly damaged, in that its surface was scratched and dented. Bench mark 101-101, northeast of the merging of Lower Placerville Road and Hoffman Street, was found with its concrete base lying at a 45 degree angle; therefore, it was not included in the leveling network. Bench mark $396+50$ is a U.S. Bureau of Reclamation bench mark set in November 1972 at milepost 7.5 of the Folsom South Canal.

Fourteen bench marks were established on June 7, 1988, by the U.S. Geological Survey and the Base Surveyor, four of which are on the base runways. Elevations and descriptions of these new bench marks are given in table 3 . other reference marks on the runway are described in table 4, which also lists the elevations obtained in 1988.

\section{ELEVATIONS OF OBSERVATION AND PRODUCTION WELLS}

The primary objective of this study was to determine the elevation of the point to which water-level measurements are referenced, known as the measuring point. For observation wells, the measuring point was identified by two hacksaw-cut grooves cut in the top of the steel casing. The hacksaw grooves had been established earlier and often were marked with white paint. The measuring point for wells where the casing was finished below grade was two hacksaw-cut grooves in the flange of a steel ring (for the cover plate), cemented in place flush with the land surface. Elevations of each measuring point for 76 observation wells are shown in table 5. Data furnished from previous surveys also are shown, with the caution that these elevations may not necessarily be for the same place on the well, because the designated measuring points were established just prior to this survey.

The measuring point of production wells generally was a pressure line valve, which usually could not accommodate a survey rod owing to its location with respect to the pump and motor assembly. In such a situation, a reference point near the measuring point was surveyed to, and the difference between the two points was measured to determine the elevation of the measuring point. The elevations of the measuring point and/or reference point, and adjacent land surface for the production wells are given in table 6 . A former production well, designated $A C \& W$, no longer has a designated measuring point. 
TABLE 2.--Elevations determined from this survey and previous leveling surveys for selected bench marks

[USGS, U.S. Geological Survey; MAFB, Mather Air Force Base; USED, U.S. Engineering Department]

\begin{tabular}{|c|c|c|c|c|}
\hline \multirow[b]{2}{*}{$\begin{array}{c}\text { Bench } \\
\text { mark } \\
(\text { fig. I) }\end{array}$} & \multicolumn{4}{|c|}{ Elevations, in feet } \\
\hline & $\begin{array}{l}\text { USGS } \\
1988\end{array}$ & MAFB & $\begin{array}{l}\text { Private } \\
\text { contractor }\end{array}$ & $\begin{array}{l}\text { Other } \\
\text { Federal } \\
\text { agencies }\end{array}$ \\
\hline Y952 & -- & - & -- & $\mathrm{I}_{88.648}$ \\
\hline Q955 & -- & -- & -- & 71.174 \\
\hline $101-020$ & 118.92 & 118.98 & 119.15 & -- \\
\hline $101-066$ & 125.67 & 125.74 & 125.74 & - \\
\hline $101-067$ & 123.84 & 123.90 & -- & -- \\
\hline $101-072$ & 82.37 & -- & 82.44 & -- \\
\hline $101-075$ & 81.60 & - & 81.67 & -- \\
\hline $101-142$ & 128.62 & 128.70 & -- & -- \\
\hline $101-143$ & 149.43 & 149.53 & 149.53 & -- \\
\hline $101-144$ & 150.20 & 150.29 & 150.29 & -- \\
\hline $101-208$ & 78.80 & 78.90 & -- & -- \\
\hline $101-215$ & 79.96 & 80.06 & -- & -- \\
\hline $101-221$ & 88.54 & 88.55 & -- & -- \\
\hline $101-222$ & 88.52 & 88.52 & - & -- \\
\hline $101-223$ & 90.69 & 90.71 & -- & -- \\
\hline $101-227$ & 72.34 & -- & -- & -- \\
\hline $101-228$ & 72.38 & - & -- & -- \\
\hline $101-229$ & 73.27 & - & -- & -- \\
\hline $101-249$ & 81.59 & -- & -- & -- \\
\hline$\times 744$ & 94.25 & 94.35 & 94.34 & 294.31 \\
\hline ALEX & 76.90 & -- & 77.00 & - \\
\hline USED $9578(S-760)$ & 85.63 & 85.75 & 85.72 & -- \\
\hline USED WT & 85.67 & 85.65 & -- & -- \\
\hline USED $6 \& G$ & 86.99 & 87.05 & 87.05 & -- \\
\hline USED G\&G & 88.90 & - & -- & -- \\
\hline $396+50$ & 142.88 & - & -- & ${ }^{3} 142.90$ \\
\hline
\end{tabular}

${ }^{1}$ National Geodetic Survey bench mark on which leveling is based.

${ }^{2}$ U.S. Engineering Department bench mark, National Geodetic Survey value from 1st order survey, 1944-45.

${ }^{3}$ U.S. Bureau of Reclamation. 
TABLE 3.--Elevations and descriptions of new bench marks

\begin{tabular}{|c|c|c|}
\hline $\begin{array}{c}\text { Bench mark } \\
\text { (fig. 1) }\end{array}$ & $\begin{array}{c}\text { Elevation } \\
\text { (feet) }\end{array}$ & Description \\
\hline HG-1 & 87.56 & $\begin{array}{l}\text { Brass tablet on southeast end of Mather Boulevard } \\
\text { bridge over Morrison Creek, near south entrance to } \\
\text { base, Wherry Housing Gate. Stamped HG-1. }\end{array}$ \\
\hline $\mathrm{H}-\mathrm{MB}-\mathrm{NE}$ & 113.75 & $\begin{array}{l}\text { Brass tablet on sidewalk at northeast corner, } \\
\text { intersection of Mather Boulevard and Branch Drive } \\
\text { West. Stamped H-MB-NE. }\end{array}$ \\
\hline $\mathrm{H}-\mathrm{MCH}-\mathrm{SE}$ & 103.83 & $\begin{array}{l}\text { Brass tablet on concrete pad for manhole cover at } \\
\text { southeast corner, intersection of Mather Boulevard } \\
\text { and west entrance to Chapel \#2. Stamped H-MCH-SE. }\end{array}$ \\
\hline$M D-N E$ & 127.82 & $\begin{array}{l}\text { Brass tablet on concrete headwall of culvert at } \\
\text { northeast corner, intersection of Mather Boulevard } \\
\text { and Douglas Road. Stamped MD-NE. }\end{array}$ \\
\hline GC-SW & 126.58 & $\begin{array}{l}\text { Brass tablet on southwest corner of bridge abutment on } \\
\text { Eagles Nest Road across Morrison Creek at Mather } \\
\text { Lake outlet, near entrance to Mather Golf Course. } \\
\text { Stamped GC-SW. }\end{array}$ \\
\hline OOI & 140.50 & $\begin{array}{l}\text { Brass tablet on southwest corner of concrete pad for } \\
\text { guardhouse at Douglas Road Gate. Stamped OOI. }\end{array}$ \\
\hline ALICIA & 73.85 & $\begin{array}{l}\text { Brass tablet on northwest side of concrete pad for } \\
\text { observation well MAFB-58, which is southeast of } \\
\text { gravel pits at southwest corner of base. } \\
\text { Stamped ALICIA. }\end{array}$ \\
\hline SAN & 75.02 & $\begin{array}{l}\text { Brass tablet on southeast corner of concrete wall of } \\
\text { Sacramento County sewer waste-treatment flow- } \\
\text { metering station near southwest end of runway. } \\
\text { Stamped SAN. }\end{array}$ \\
\hline QUINN & 69.94 & $\begin{array}{l}\text { Brass tablet } 38 \text { feet southeast of center line of } \\
\text { Perimeter Road in center of north concrete weir } \\
\text { training wall beside enclosure } 7100 \text {. Stamped QUINN. }\end{array}$ \\
\hline JOHN & 67.10 & $\begin{array}{l}\text { Brass tablet on northwest side of concrete pad for } \\
\text { observation well MAFB-59, which is across road from } \\
\text { jet test cell near southwest corner of base. } \\
\text { Stamped JOHN. }\end{array}$ \\
\hline
\end{tabular}


TABLE 3.--Elevations and descriptions of new bench marks--Continued

$\begin{array}{ccc}\text { Bench mark } & \text { Elevation } & \text { Description } \\ (\text { fig. 1) } & \text { (feet) } & \end{array}$

\begin{tabular}{|c|c|c|}
\hline $4 R$ & 75.00 & $\begin{array}{l}\text { Brass tablet at center line of southwest end of runway } \\
4 \mathrm{R}(22 \mathrm{~L}) \text {; southwest side of intersection with } \\
\text { taxiway G; } 14 \text { feet runway side of threshold. } \\
\text { Stamped 4R. }\end{array}$ \\
\hline $4 \mathrm{~L}$ & 78.72 & $\begin{array}{l}\text { Brass tablet at center line of southwest end of runway } \\
4 \mathrm{~L}(22 \mathrm{R}) ; \text { southwest side of intersection with } \\
\text { taxiway E; } 14 \text { feet runway side of threshold and } \\
\text { reference mark PK. Stamped } 4 \mathrm{~L} \text {. }\end{array}$ \\
\hline $22 \mathrm{R}$ & 91.78 & $\begin{array}{l}\text { Brass tablet at center line of northeast end of runway } \\
22 \mathrm{R} \text {, at northeast side of intersection with taxiway } \\
\text { B; } 14 \text { feet runway side of threshold. Stamped } 22 \mathrm{R} \text {. }\end{array}$ \\
\hline $22 \mathrm{~L}$ & 95.97 & $\begin{array}{l}\text { Brass tablet at center line of northeast end of runway } \\
22 \mathrm{~L} \text {, at northeast side of intersection with taxiway } \\
\mathrm{A} ; 14 \text { feet runway side of threshold. Stamped } 22 \mathrm{~L} \text {. }\end{array}$ \\
\hline
\end{tabular}

TABLE 4.--Elevations and descriptions of runway reference marks

\begin{tabular}{|c|c|c|}
\hline$\underset{(f i g \cdot 1)}{\operatorname{mark}}$ & $\begin{array}{l}\text { Elevation } \\
\quad \text { (feet) }\end{array}$ & Description \\
\hline TACAN & 94.61 & $\begin{array}{l}\text { Painted circle on taxiway } A \text {, between northeast ends of } \\
\text { runways } 22 \mathrm{~L} \text { and } 22 \mathrm{R} \text {. }\end{array}$ \\
\hline PK & 78.58 & $\begin{array}{l}\text { Steel pipe driven flush with pavement at center line } \\
\text { of southwest end of runway } 22 \mathrm{R} \text {, at threshold; } \\
14 \text { feet southwest of BM } 4 \mathrm{~L} \text {. }\end{array}$ \\
\hline ARS & 82.40 & $\begin{array}{l}\text { Brass tablet centered between runways } 22 \mathrm{R} \text { and } 22 \mathrm{~L} ; \\
\text { southwest edge of taxiway D; known as Airport } \\
\text { Reference Station. Set by National Geodetic Survey. } \\
\text { Stamped ARS } 1983 \text {. }\end{array}$ \\
\hline
\end{tabular}


TABLE 5.--Elevations of measuring point for observation wells

[See figure 2 for location of observation wells]

\begin{tabular}{|c|c|c|c|c|c|}
\hline \multirow[b]{2}{*}{$\begin{array}{l}\text { Mather } \\
\text { Air Force } \\
\text { Base well }\end{array}$} & \multicolumn{5}{|c|}{ Elevations, in feet } \\
\hline & $\begin{array}{l}\text { June } 1988 \\
\text { survey }\end{array}$ & $\begin{array}{l}\text { Previous } \\
\text { surveys }\end{array}$ & $\begin{array}{l}\text { Mather } \\
\text { Air Force } \\
\text { Base well }\end{array}$ & $\begin{array}{c}\text { June } 1988 \\
\text { survey }\end{array}$ & $\begin{array}{l}\text { Previous } \\
\text { surveys }\end{array}$ \\
\hline 1 & 131.68 & -- & 38 & 77.75 & 77.79 \\
\hline 2 & 130.78 & -- & 39 & 75.00 & 75.03 \\
\hline 3 & 128.04 & -- & 40 & 39.54 & 39.06 \\
\hline 4 & 173.38 & -- & 41 & 73.64 & 73.16 \\
\hline 5 & 135.21 & -- & 42 & 74.98 & 74.74 \\
\hline 6 & 98.34 & -- & 43 & 75.15 & 74.97 \\
\hline 7 & 74.75 & -- & 44 & 76.30 & 75.49 \\
\hline 8 & 76.06 & -- & 45 & 77.75 & 76.94 \\
\hline 9 & 79.36 & -- & 46 & 68.60 & 68.31 \\
\hline 10 & 81.11 & -- & 47 & 77.24 & 76.53 \\
\hline 11 & 80.38 & -- & 48 & 75.63 & 75.32 \\
\hline 12 & 96.52 & 96.53 & 49 & 92.26 & 91.47 \\
\hline 13 & 92.21 & 91.89 & 50 & 124.34 & 123.43 \\
\hline 14 & 92.45 & 92.59 & 51 & 126.72 & 126.35 \\
\hline 15 & 92.12 & 92.20 & 52 & 123.78 & 122.08 \\
\hline 16 & 120.04 & 120.04 & 53 & 131.33 & 133.43 \\
\hline 17 & 121.66 & 121.66 & 54 & 118.68 & 117.70 \\
\hline 18 & 119.78 & 119.68 & 55 & 40.03 & 39.19 \\
\hline 19 & 131.40 & 131.41 & 56 & 74.17 & 73.40 \\
\hline 20 & 127.00 & 127.06 & 57 & 75.34 & 74.38 \\
\hline 21 & 127.79 & 127.77 & 58 & 75.52 & 74.60 \\
\hline 22 & 132.67 & 137.95 & 59 & 69.62 & 69.10 \\
\hline 23 & 132.42 & 132.52 & 60 & 77.48 & 76.90 \\
\hline 24 & 126.80 & 126.67 & 61 & 78.43 & 78.13 \\
\hline 25 & 125.41 & 125.89 & 62 & 80.06 & 78.99 \\
\hline 26 & 122.80 & 122.83 & 63 & 76.09 & 75.08 \\
\hline $27 \mathrm{~B}$ & 147.93 & 147.96 & 64 & 132.38 & 123.30 \\
\hline $27 \mathrm{C}$ & 147.56 & 147.58 & 65 & 134.28 & 128.71 \\
\hline 28 & 135.20 & 134.79 & 66 & 93.51 & 93.03 \\
\hline 29 & 131.27 & 130.71 & 67 & 129.41 & 129.08 \\
\hline 30 & 134.25 & 133.90 & 68 & 131.44 & 130.77 \\
\hline 31 & 92.98 & 93.01 & 69 & 133.87 & 133.40 \\
\hline 32 & 93.53 & 93.33 & 70 & 123.60 & 123.51 \\
\hline 33 & 80.88 & 80.81 & 71 & 131.48 & 128.22 \\
\hline 34 & 81.33 & 80.97 & 72 & 117.07 & 116.95 \\
\hline 35 & 80.65 & 80.14 & 73 & 92.76 & 92.67 \\
\hline 36 & 82.27 & 81.85 & 75 & 133.42 & 127.38 \\
\hline 37 & 78.82 & 78.63 & 76 & 132.92 & 123.33 \\
\hline
\end{tabular}


TABLE 6.--Elevations of measuring point and/or reference point of production wells, and adjacent land surface

[MP, measuring point; RP, reference point; LS, land surface]

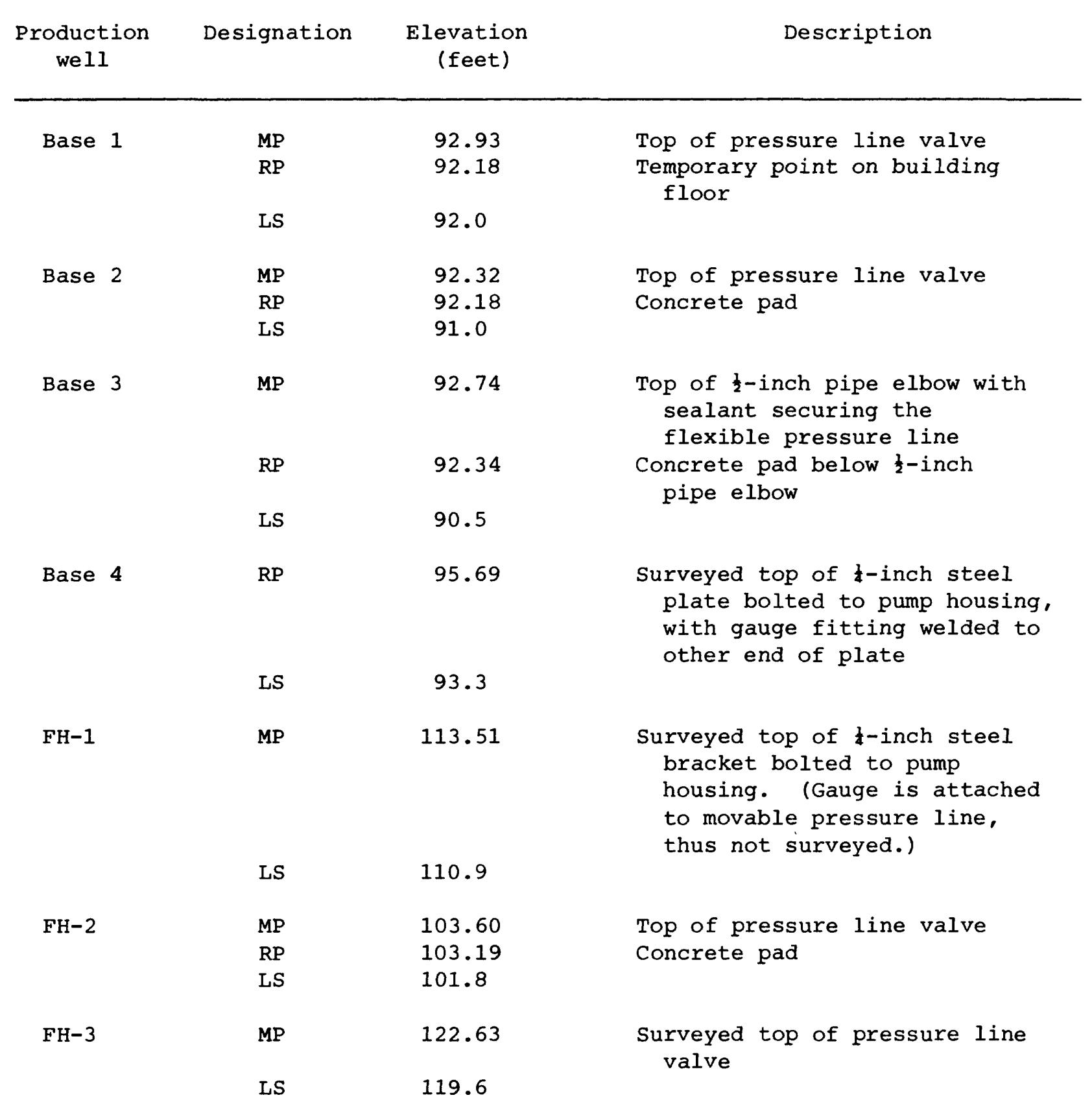


TABLE 6.--Elevations of measuring point and/or reference point of production wells, and adjacent land surface--Continued

$$
\text { [MP, measuring point; RP, reference point; LS, land surface] }
$$

\begin{tabular}{|c|c|c|c|}
\hline $\begin{array}{l}\text { Production } \\
\text { well }\end{array}$ & Designation & $\begin{array}{l}\text { Elevation } \\
\quad \text { (feet) }\end{array}$ & Description \\
\hline \multirow[t]{3}{*}{$\mathrm{FH}-4$} & MP & 112.93 & Top of pressure line valve \\
\hline & $\mathrm{RP}$ & 112.14 & Concrete pad \\
\hline & LS & 110.6 & \\
\hline \multirow[t]{2}{*}{$\mathrm{FH}-5$} & MP & 124.51 & $\begin{array}{l}\text { Surveyed top of pressure } \\
\text { line valve }\end{array}$ \\
\hline & LS & 121.5 & \\
\hline \multirow[t]{3}{*}{$\mathrm{FH}-6$} & MP & 115.59 & Top of pressure line valve \\
\hline & $\mathrm{RP}$ & 114.43 & Top of bolt on concrete pad \\
\hline & LS & 112.8 & \\
\hline \multirow[t]{2}{*}{$\mathrm{GC}-1$} & MP & 126.25 & $\begin{array}{l}\text { Surveyed top of } 2 \text {-inch pipe } \\
\text { set at an angle on the } \\
\text { east side of concrete pad }\end{array}$ \\
\hline & LS & 124.0 & \\
\hline \multirow[t]{2}{*}{$\mathrm{GC}-2$} & MP & 139.41 & $\begin{array}{l}\text { Surveyed top of pressure } \\
\text { line valve }\end{array}$ \\
\hline & LS & 137.7 & \\
\hline \multirow[t]{3}{*}{$\mathrm{K}-9$} & MP & 151.25 & $\begin{array}{l}\text { Top of horizontal pressure } \\
\text { line valve }\end{array}$ \\
\hline & RP & 151.44 & $\begin{array}{l}\text { Top of carpenters level } \\
\text { placed on horizontal } \\
\text { pressure line valve }\end{array}$ \\
\hline & LS & 149.9 & \\
\hline \multirow[t]{2}{*}{ JTC } & MP & 70.62 & $\begin{array}{l}\text { Surveyed top of horizontal } \\
\text { pressure line valve }\end{array}$ \\
\hline & LS & 69.1 & \\
\hline \multirow[t]{2}{*}{$\begin{array}{c}\text { AC\&W } \\
\text { (former) }\end{array}$} & $\mathrm{RP}$ & 134.64 & $\begin{array}{l}\text { Surveyed top of 1-inch } \\
\text { diameter circular steel } \\
\text { protrusion on west side of } \\
\text { 5-inch diameter discharge } \\
\text { pipe to south wall. } \\
\text { (Pressure line is movable, } \\
\text { thus not surveyed.) }\end{array}$ \\
\hline & LS & 133.2 & \\
\hline
\end{tabular}




\section{SUMMARY}

Knowledge of the depth to the water table at Mather Air Force Base is an integral part of the Installation Restoration Program. Measurements made at water-level-observation wells and production wells on the base rely on accurate determinations of the elevations of the measuring points of these wells. Differential surveying produced accurate elevations for 76 observation wells, 15 production wells, and 41 bench marks on Mather Air Force Base, all tied to a common datum--the elevation of bench mark Y952, published in 1962.

\section{REFERENCE CITED}

National Oceanic and Atmospheric Administration, Federal Geodetic Control Committee, 1980, Classification, standards of accuracy, and general specifications of geodetic control survey: $12 \mathrm{p}$. 